\title{
Influence of Nitrocarburizing on Increasing the Service Life of Elastic Elements of Direct-Flow Valves
}

Jan Krmela (0000-0001-9767-9870) 1,2, Tetiana Hovorun 3 , Kristina Berladir (0000-0002-4287-8204)3 , Artem Artyukhov (0000-0003-1112-6891) $)^{4}$, Serhii Kasian ${ }^{5}$

${ }^{1}$ Faculty of Mechanical Engineering, J. E. Purkyně University in Ustí nad Labem. Pasteurova 3334/7, 40001 Ustí nad Labem. Czech Republic. E-mail: jan.krmela@ujep.cz

${ }^{2}$ Faculty of Industrial Technologies in Púchov, Alexander Dubček University of Trenčín. I. Krasku 491/30, 02001 Púchov. Slovak Republic. E-mail: jan.krmela@tnuni.sk

${ }^{3}$ Faculty of Technical Systems and Energy Efficient Technologies, Sumy State University. Rymskogo-Korsakova st., 2, 40007, Sumy. Ukraine. E-mail: hovorun@pmtkm.sumdu.edu.ua.kr.berladir@pmtkm.sumdu.edu.ua

${ }^{4}$ Academic and Research Institute of Finance, Economics and Management, Sumy State University. RymskogoKorsakova st., 2, 40007, Sumy. Ukraine. E-mail: a.artyukhov@pohnp.sumdu.edu.ua

${ }^{5}$ Faculty of Finances and Economics, Dnipro University of Technology. Av. Dmytra Yavornytskogo 19, 49005, Dnipro. Ukraine. E-mail: Kasian.S.Ya@nmu.one

The effect of the nitrocarburizing process in pastes with heating in a chamber furnace on the structure and strength characteristics of $09 \mathrm{Cr} 15 \mathrm{Ni} 8 \mathrm{Al}$ corrosion-resistant steel was investigated. The technology of thermochemical treatment was developed, which included nitrocarburizing in pastes with heating in a chamber furnace at different holding times. The thickness of the diffusion layer and its microhardness were determined after nitrocarburizing. To determine the efficiency and select the modes of thermochemical treatment, tests were carried out for the investigated steel's strength characteristics. The main feature of the structure of the diffusion layers of valve steels, obtained by nitrocarburizing in the nitrogencarbon paste, is the presence of an inhomogeneous layer with clearly distinguished zones.

Keywords: Direct-Flow Valve Plates, Nitrocarburizing in Pastes, Corrosion-Resistant Steel, Carburizer, Fatigue Strength.

\section{Introduction}

Compressor machines are used in various sectors of the national economy [1] but found the most significant application in the chemical industry $[2,3]$, where they are one of the main links in technological lines for the production of mineral fertilizers, compressed gases of high purity and polyethylene. Failure in compressor machines' operation leads to a decrease in production and large material losses [4].

Chemical industries that use multiphase gas-solid systems are highly dependent on the quality of the movement of compressed gases. This is especially important when, due to the gas flow, various gas-dispersed systems are created, for example, fluidized beds of various configurations $[5,6]$. The efficiency of the granulation processes [7] and drying [8, 9] using a fluidized bed largely depends on the correct choice of the type of compressor and its mode of operation. As the results of computer modeling of hydrodynamic flow conditions, for example, in vortex granulators, show, the operating modes of this equipment are highly dependent on changes in the characteristics of the gas flow (fluidizing agent) [10,11]; the same can be said in application to the calculation of the residence time of dispersed particles in a granulator [12]. The optimal choice of the design of the compressor and the mode is important not only in the computer simulation of the hydrodynamics of the gas flow but also in the creation of proprietary software products for the calculation of granulation equipment $[13,14]$.

Specially designed (or modernized) reciprocating compressors, in which compression is carried out without oil lubrication, are widely used. Such compressors are insensitive to solvents, which allows ensuring the required quality of the final product, as well as safety when compressing many aggressive and explosive gases [15].

Despite the variety of brands and designs of reciprocating compressors, they all have almost the same basic units (cylinders, pistons, crankshafts, etc.) (Fig. 1) [1]. One of the main components of compressors is suction and discharge valves. Many characteristics of the compressors depend on the quality of the valves, and most importantly, the cost of compressed air production [16].

Direct-flow valves are widely introduced in compressor construction. These valves provide the lowest losses during the operation of the compressors be- 
cause they have a large flow area and thin elastic elements (plates), which require little effort to remove.

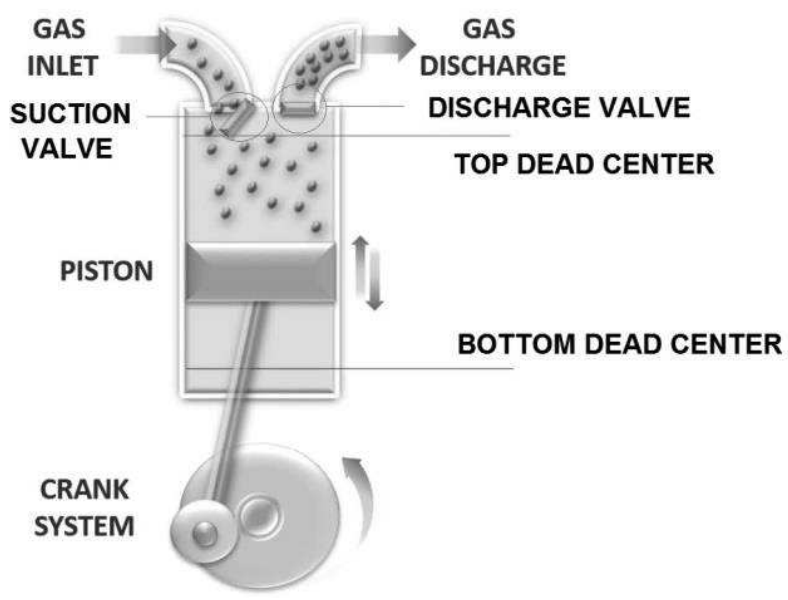

Fig. 1 Scheme of a reciprocating piston compressor [1]

As the experience of compressor operation shows, direct flow valves, in comparison with valves of other designs (poppet, plate, etc.), increase air supply, reduce power consumption, reduce noise during compressor operation and create conditions for longer compressor operation.

The main disadvantage limiting the widespread use of direct flow valves is their insufficiently high reliability because each of these valves has many elastic elements (plates) that do not have equal strength. The difference in individual plates' service life in one valve can reach $300 \%$, and if even one plate breaks, the valve becomes inoperative.

Direct-flow valve plates operate under repeated force loading and are susceptible to fatigue failure. The study of fatigue processes occurring in the material of the plates and the increase of their fatigue strength is a very urgent task, the solution of which will significantly increase the reliability of the operation of air compressors.

\section{Statement of the goal and objectives of the study}

One of the important parts of the compressor is the elastic elements of the direct-flow strip valve. The operating conditions of the plates of direct-flow valves are characterized by the cyclical nature of the application of alternating, dynamic, and contact loads at elevated temperatures (up to $200{ }^{\circ} \mathrm{C}$ ) and the aggressiveness of the compressing gas. The presence of stress concentrators on the mating parts and the ingress of foreign bodies under the elastic elements requires the material under these conditions to withstand the action of peak loads without destruction, that is, to have a high level of resistance to brittle fracture during fatigue.
For the manufacture of elastic elements of compressor machines, thin-sheet spring steels are used. At present, in engineering calculations of plates of directflow valves, the determining factor of reliability is the values of strength and relative elongation, which cannot fully characterize the properties of steel 09Cr15Ni8Al.

The test results showed that the effect of temperature, cyclic alternating sign and shock loads on high strength maraging steels, including those of the transitional class, can lead to a change in the physical and mechanical properties. Moreover, depending on the deformation history and the subsequent cycle of treatments, the structure of the material has a different level of resistance to fracture processes.

Improving the reliability of the elastic elements of compressor machines requires the development and application of new hardening methods that would show good performance and the degree of reliability in the most severe operating conditions.

The purpose of this work is to increase the service life of the elastic elements of compressor machines by creating a structural state of thin sheet material with a certain set of physical and mechanical properties that provide high resistance to fracture under operating conditions.

\section{Prospects for the use of nitrocarburizing to increase the strength of steel}

To increase fatigue endurance and wear resistance, the hardness of the steel surface should be increased, which can be achieved by surface hardening, chemical thermal treatment, or plastic deformation to create residual compressive stresses on the surface of parts.

One of the chemical and thermal treatment methods of metals and alloys is a high-speed process of nitrocarburizing to obtain reinforced layers with high microhardness [17] and wear resistance [18].

Nitrocarburizing has significant advantages over carburizing [19]:

- lower temperature $\left(840-860{ }^{\circ} \mathrm{C}\right.$ instead of $930-9500^{\circ} \mathrm{C}$ ), which reduces deformation and warping of the part during quenching;

- slowing down the growth of austenitic grain due to the lower process temperature, which allows to carry out quenching directly from the temperature of nitrocarburizing;

- higher wear resistance, fatigue strength, and corrosion resistance.

In addition to high-temperature nitrocarburizing in recent years, low-temperature nitrocarburizing at 540 $610^{\circ} \mathrm{C}$ for 1 to 8 hours has been increasingly used [20, 
21]. Suppliers of nitrogen and carbon are urea (carbamide), melamine, ethanolamine and other substances in different ratios [22, 23].

Unlike cyaniding, nitrocarburizing does not require the use of harmful salts [24] and is much cheaper. Therefore, this method of surface hardening of products is the most common. The process is carried out in a mixture of gases containing carbon and ammonia (80-90\% $\mathrm{CH}_{4}$ and $20-10 \% \mathrm{NH}_{3}$ ) at a temperature of $840-860{ }^{\circ} \mathrm{C}$. As the temperature increases, the saturation with carbon increases and with nitrogen decreases. At the specified temperature, the surface layer contains $\sim 1.0 \% \mathrm{C}$ and $0.5 \% \mathrm{~N}$ [25]. Despite the lower process temperature compared to carburizing, the saturation rate remains almost the same -0.15 $\mathrm{mm} / \mathrm{h}$. The hardness of the surface after nitrocarburizing is slightly higher than after carburizing. This allows reducing the required thickness of the saturated layer to $0.6-1.0 \mathrm{~mm}$ [26]. After such treatment, the nitrocarburized layer has the structure of fine-crystalline martensite and dispersed carbonitrides [27, 28].

Nitrocarburizing is characterized by a diverse combination of control factors [18]. In this regard, it is difficult to provide experimentally the optimal choice of technological mode. Especially for the strengthening of details from steels to which operational characteristics high, and sometimes mutually exclusive requirements are shown. [19].

The decision of ecological costs of diffusion hardening and increase of operational properties of a surface layer relates to the development and use of specially developed powder mixes (coatings, pastes). They are called saturating mediums (carburizer) [29].

The following three main requirements are imposed on the saturating medium:

- medium (carburizer) must provide the necessary strengthening of parts and components of different structural steels in each temperature range in the air without the use of additional equipment [30];

- the carburizer must work, both in the conditions of small-scale and mass production, to be convenient for strengthening details of various forms and the sizes with the use of the simplest thermal equipment;

- the saturating medium should not consist of scarce and expensive materials - components;

- the carburizer must be easy to use, non-toxic and meet all the rules of safety at work, as well as be non-energy consuming.

For elastic elements of direct-flow strip valves of compressors, it is necessary to carry out hardening not completely on all surface and separate sites. For this purpose, the development of technology for strengthening nitrocarburizing in pastes, which is carried out in this work, is promising.

\section{Methods of obtaining samples and equip- ment for research}

Valve plates (Fig. 2) are usually made of expensive stainless steel $09 \mathrm{Cr} 15 \mathrm{Ni} 8 \mathrm{Al}$ (Table 1) and subjected to heat treatment, providing the tape with maximum elasticity (quenching + tempering at a temperature of $350-400{ }^{\circ} \mathrm{C}$ ). To ensure reliable operation of valves, the problem of increasing the fatigue strength of valve plates comes to the fore.

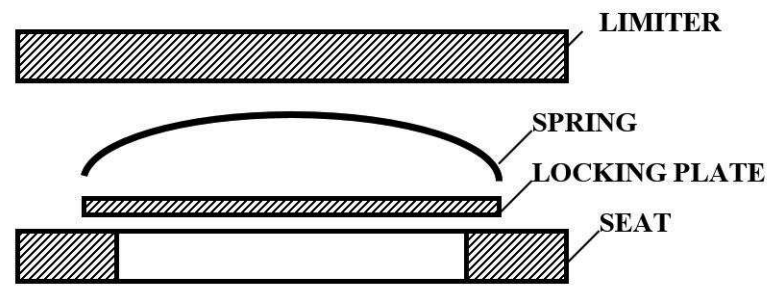

Fig. 2 Scheme of construction element of a direct-flow strip valves

The chemical composition of an investigated steel is presented in Table 1 .

Tab. 1 The chemical composition of corrosion-resistant steel of austenitic-martensitic class, \% by weight [31]

\begin{tabular}{|c|c|c|c|c|c|c|c|c|}
\hline $\mathrm{C}$ & $\mathrm{Si}$ & $\mathrm{Mn}$ & $\mathrm{Cr}$ & $\mathrm{Ni}$ & $\mathrm{Al}$ & $\mathrm{S}$ & $\mathrm{P}$ & $\mathrm{Fe}$ \\
\hline up to 0.09 & up to 0.8 & up to 0.8 & $14.0-16.0$ & $7.0-9.4$ & $0.7-1.3$ & up to 0.025 & up to 0.035 & $\sim 74.0$ \\
\hline
\end{tabular}

It is possible to optimize the fatigue characteristics of steel by selecting heat treatment modes. In this case, although the structure of the steel noticeably affects the absolute values of the fatigue parameters, it does not change the mechanism of fatigue failure. This mechanism appears to be the same for different structural components.

The container with the samples was heated in a mine laboratory electric furnace SShOL-12-M3-Ts4.
The container was placed in furnace preheated to the required temperature. After the temperatures were equalized, the saturation time was started. Cooling of samples after nitrocarburizing was carried out in the water, for which a special device, a separator, was used. The container with a lid, after being removed from the furnace, was placed in a slot on the separator's rotary device and secured with a screw. Then the lid was removed from the container and the container 
was tipped inside the separator. The contents of the container were poured onto an inclined grate, through which the filler and used coating spilled down into a special box. The samples slid along the grate and fell into a tank of cold water. Thus, the minimum time (less than one minute) was spent on unpacking the container, and the samples did not have time to cool before entering the water.

After nitrocarburizing and cooling in water, microsections were made on the samples, on which the microstructure of the diffusion layers was studied, and the microhardness was measured.

Methods of research - metallographic and electron-metallographic studies of the structure of the surface layer of steel, measuring the microhardness of the nitrocarburized layer.

In the study, a metallographic microscope MIM-7, a microhardness tester PMT-3, and an eyepiece micrometer were used, which made it possible to make measurements with an accuracy of $0.3 \mu \mathrm{m}$. Metallographic sections on nitrocarburized steel $09 \mathrm{Cr} 15 \mathrm{Ni} 8 \mathrm{Al}$ to reveal the microstructure were etched with a solution of aqua regia $\left(50 \% \mathrm{HNO}_{3}\right.$ and $50 \%$
$\mathrm{HCl})$.

\section{Conducting a process of nitrocarburizing when using different compositions of pastes}

In order to increase the operational properties of the investigated steel, the following technological process was applied - nitrocarburizing using a paste-like carbon-nitrogen carburizer having carbon and nitrogen-containing components. The paste is applied directly to the reinforcing surfaces, which maximizes the reaction of the generation of active nitrogen and carbon atoms to the surface of the steel. Where they are here are adsorbed and diffused in the depth of the product. The consumption of the components of the carburizer with such a mechanism is minimal, and saturated ability is high. The carburizer in the form of a paste can be applied to any surface. The process can be carried out in containers, which is convenient for both serial and single production. The results of the nitrocarburizing of steel $09 \mathrm{Cr} 15 \mathrm{Ni} 8 \mathrm{Al}$ in pastes of various compositions are presented in Table 2.

Tab. 2. The saturating ability of pasty carburizers

\begin{tabular}{|c|c|c|c|c|}
\hline \multirow{2}{*}{$\begin{array}{l}\text { № car- } \\
\text { burizer }\end{array}$} & \multirow{2}{*}{$\begin{array}{l}\text { Name of } \\
\text { components }\end{array}$} & \multirow{2}{*}{$\begin{array}{l}\text { Component con- } \\
\text { tent, } \\
\% \text { masses }\end{array}$} & \multicolumn{2}{|c|}{$\begin{array}{l}\text { The depth of the diffusion layer on steel 09Cr15Ni8Al, } \\
\qquad m^{*}\end{array}$} \\
\hline & & & $\begin{array}{l}\text { Temperature of nitrocarburiz- } \\
\text { ing } \\
550{ }^{\circ} \mathrm{C}\end{array}$ & $\begin{array}{c}\text { Temperature of nitrocar- } \\
\text { burizing } \\
650^{\circ} \mathrm{C}\end{array}$ \\
\hline 1 & $\begin{array}{l}\left(\mathrm{NH}_{2}\right) \mathrm{CO} \\
\mathrm{K}_{4}\left[\mathrm{Fe}(\mathrm{CN})_{6}\right] \\
\text { Soot }\end{array}$ & $\begin{array}{l}10 \\
50 \\
40\end{array}$ & $0.0225 / 0$ & $0.0615 / 0.0285$ \\
\hline 2 & $\begin{array}{c}\left(\mathrm{NH}_{2}\right) \mathrm{CO} \\
\mathrm{K}_{4}\left[\mathrm{Fe}(\mathrm{CN})_{6}\right] \\
\text { Soot }\end{array}$ & $\begin{array}{l}30 \\
30 \\
40\end{array}$ & $0.0405 / 0.0067$ & $0.0608 / 0.0315$ \\
\hline 3 & $\begin{array}{c}\left(\mathrm{NH}_{2}\right) \mathrm{CO} \\
\mathrm{K}_{4}\left[\mathrm{Fe}(\mathrm{CN})_{6}\right] \\
\text { Soot }\end{array}$ & $\begin{array}{l}50 \\
10 \\
40\end{array}$ & $0.0495 / 0.0157$ & $0.0675 / 0.0337$ \\
\hline
\end{tabular}

According to the results of the experiment carried out, the carburizers of all studied compositions ensured the production of diffusion layers on the surface, noticeably differ in the structure from the base metal. In this case, the composition of the carburizer sufficiently affects the depth and structure of these layers only at a low temperature of nitrocarburizing $\left(550^{\circ} \mathrm{C}\right)$ (Fig. 3). At a higher temperature $\left(650^{\circ} \mathrm{C}\right)$, the diffusion layers turned out to be almost identical when using all the carburizers studied.

Thus, for the nitrocarburizing of the plates of the strip direct-flow valve of the piston compressor, it can be recommend a paste-shaped carburizer of the following composition (\% masses): carbamide $-20 \ldots .25$; potassium ferricyanide $-25 \ldots 20$; soot -55 ; dextful glue as a liquid component for obtaining a paste-like consistency.

Analyzing the experimental data obtained, it can be concluded that the influence of both nitrocarburizing factors is significant to the depth of the carbonitride zone, that is, the temperature and duration of the process.

The temperature intensively increases the overall depth of the nitrocarburized layer. The pattern is observed in the process of growth of thickness of carbonitride crust on the surface of nitrocarburized steels with an increase in saturation temperature. Only in this case, the growing intensity of the crust (carbonitrides zones) is significantly less than the intensity of 
the growth of the depth of the diffusion layer with increasing the temperature of nitrocarburizing (Fig. 4).

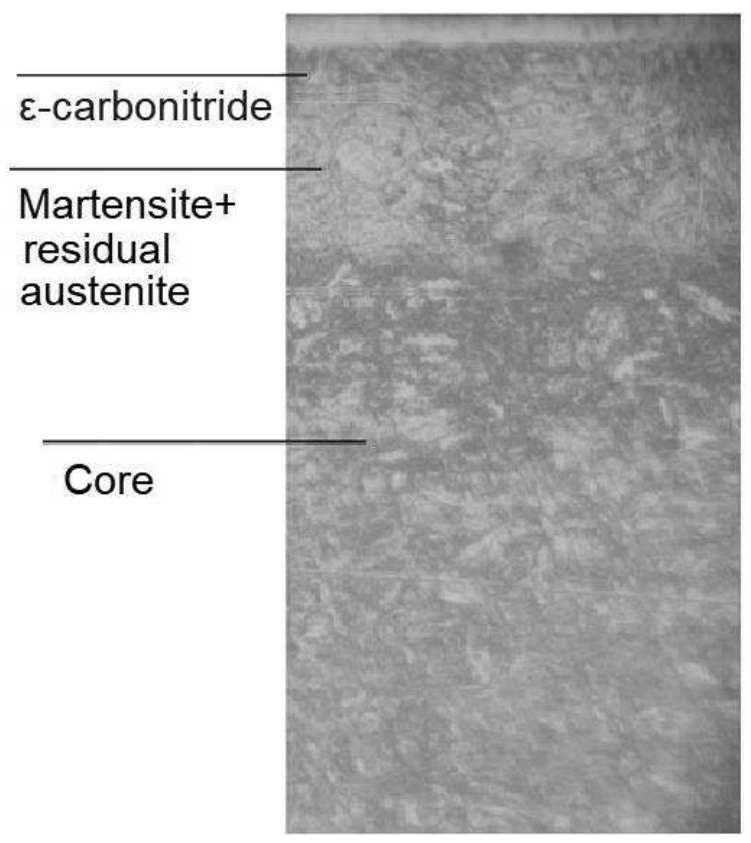

Fig. 3 Microstructure of steel 09Cr15Ni8 Al after nitrocarburizing in the nitrogen-carbon paste at $550^{\circ} \mathrm{C}, \times 200$

Depth of carbonitride zone, $\mathrm{mm}$

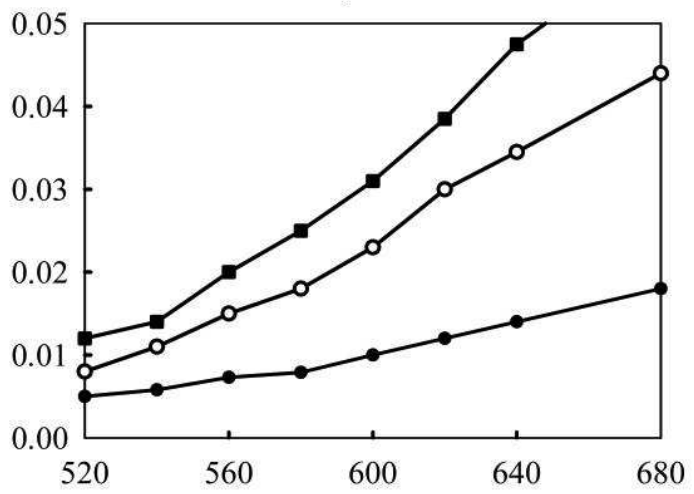

Temperature of nitrocarburizing, ${ }^{\circ} \mathrm{C}$

Fig. 4 The dependence of the depth of the carbonitride zone in the diffusion layers of the nitrocarburized steel $09 \mathrm{Cr} 15 \mathrm{Ni} i \mathrm{Al}$ on the temperature of nitrocarburizing with the different duration of the process: -1 hour; $\bigcirc-3$ hours; -5 hours

\section{Features of the structure of nitrocarbu- rized layers of steel $09 \mathrm{Cr} 15 \mathrm{Ni} 8 \mathrm{Al}$}

At the beginning of low temperature nitrocarburizing (at temperatures below A1), mainly nitrogen diffuses into the iron. This is because the rate of diffusion of nitrogen in ferrite is several orders of magnitude higher than the rate of diffusion of carbon. As the ferrite is saturated with nitrogen, which occurs very quickly, the austenitization of the diffusion layer begins and diffusion of carbon becomes possible over the austenite regions. The austenitic regions expand intensively due to the contraction of the ferritic ones.
As the diffusion layer is saturated with carbon and nitrogen, with an excess of these elements above the solubility limits, carbonitride phases are formed on the surface.

According to the kinetics of the process, nitrocarburizing can be rather conditionally divided into two stages. The first stage is the complete austenitization of the surface zone of the part (until the disappearance of ferrite areas) and the formation of a carbonitride crust on the surface. The second stage is an increase in the layer thickness due to the diffusion of nitrogen and carbon through carbonitrides and austenite.

Since the rate of nitrogen diffusion in austenite is slightly lower than in ferrite, the depth of the diffusion layer, after its austenitization and the formation of a carbonitride crust, increases very slowly. Therefore, an increase in the duration of low temperature nitrocarburizing above a certain optimal value does not make sense (in contrast to the nitriding process). At low temperatures, the saturation rate is limited by the duration of the first stage of nitrocarburizing, and this, in turn, by the activity of the saturating medium (see Table 2).

With an increase in the duration of nitrocarburizing in an environment rich in active carbon, its predominant diffusion into the steel through the austenite layer occurs. In this case, nitrogen desorption occurs, that is, the transfer of a part of nitrogen atoms from the metal surface to the gaseous medium. It is proved that desorption is not a consequence of changes in the composition of the saturating medium but is the result of the kinetic interaction of nitrogen and carbon atoms in steel.

The main feature of the structure of the diffusion layers of valve steels, obtained by nitrocarburizing in the nitrogen-carbon paste, is the presence of several clearly distinguished zones in these layers. The layer turns out to be heterogeneous. Moreover, the number and type of these zones depend mainly on the temperature of nitrocarburizing.

When nitrocarburizing steel $09 \mathrm{Cr} 15 \mathrm{Ni} 8 \mathrm{Al}$ at a temperature of $550{ }^{\circ} \mathrm{C}$ for 3 hours, a diffusion layer $0.025 \mathrm{~mm}$ thick was formed on its surface. It consists of 2 zones: on the surface there is a thin non-etched strip $(\sim 10 \mu \mathrm{m})$ and under it is a deeper dark zone with a small amount of light inclusions. The microhardness of the light strip on the surface of the diffusion layer reaches $\mathrm{H} \mu 50=1350-1400$, and the microhardness of the dark zone is $H \mu 50=850-650$. Deeper than the nitrocarburized layer, the microhardness of steel drops sharply and amounts to $\mathrm{H} \mu 50=320$.

A nitrocarburized layer obtained at an elevated temperature $\left(650^{\circ} \mathrm{C}\right)$ differs significantly from a layer obtained at a low temperature $\left(550^{\circ} \mathrm{C}\right)$. The total depth of the nitrocarburized layer is $\sim 0.042 \mathrm{~mm}$, which is approximate twice the thickness of the layer obtained at low temperatures. This diffusion layer 
consists of three zones: a thin light border on the surface, under it there is a thicker also light stripe and, finally, under the light zones, an even thicker dark layer, which gradually turns into a core structure.

The microhardness of the zones of the diffusion layer of steel differs markedly from each other. The thinnest surface zone is distinguished by the maximum hardness $\mathrm{H} \mu 50=1350-1400$, the microhardness of the underlying light strip is slightly lower than $\mathrm{H} \mu 50=1200$. The microhardness of the dark zone of the diffusion layer is, as in the first case, $\mathrm{H} \mu 50=820$ 600 .

The hardness of the structures of nitrocarburized steel under the diffusion layer is $\mathrm{H} \mu 50=300-280$, which is slightly lower than the hardness of the core obtained at low temperatures.

As for determining the microhardness of nitrocarburized structures, it should be noted that the results of measuring the microhardness have a very large scatter ( $\pm 1000 \mathrm{MPa}$ and even more), which apparently indicates the inhomogeneity of the structure of diffusion layers of nitrocarburized steel $09 \mathrm{Cr} 15 \mathrm{Ni} 8 \mathrm{Al}$.

Considering the above information about the peculiarities of joint diffusion of nitrogen and carbon during nitrocarburizing of steel, the structural components obtained in the diffusion layers can be identified as follows.

At a low temperature of nitrocarburizing steel $09 \mathrm{Cr} 15 \mathrm{Ni} 8 \mathrm{Al}$, a thin crust of $\varepsilon$-carbonitride is formed on its surface; with an increase in the temperature of nitrocarburizing, a carbonitride isomorphic with cementite is formed on the surface. A rather deep zone of $\varepsilon$-carbonitride is formed under a thin layer of this carbonitride. Under the crust of carbonitrides in all diffusion layers of nitrocarburized steel $09 \mathrm{Cr} 15 \mathrm{Ni} 8 \mathrm{Al}$ there is a sufficiently deep zone of solid nitrogenouscarbonaceous solution. The sufficiently high hardness of this zone indicates that it is based on martensite, which is formed during quenching of the nitrocarburized layer in water.

It should be noted here that a carbonitride crust on the surface of the diffusion layer can be obtained only by nitrocarburizing steels in mediums with a relatively high ability to saturate the metal surface with nitrogen. With an increase in the temperature of nitrocarburizing, the activity of carbon increases. On the surface of the diffusion layer, cementite is formed, in which some carbon atoms in the crystal lattice are replaced by nitrogen. Carbonitride that is an isomorphic with cementite, is formed only on the surface of the layer. Under it is a much larger zone of homogeneous $\varepsilon$-carbonitride.

At the lower boundary of the $\varepsilon$-carbonitride crust in equilibrium with this carbonitride is in all cases austenite with a content of $0.95-1.1 \% \mathrm{Ni}$ and $\sim 0.6 \% \mathrm{C}$. Supercooled austenite of this composition is very stable, therefore, near the boundary with the carbonitride layer, neither pearlite nor bainite is formed, but austenite is transformed into martensite. However, the temperature of the onset of martensitic transformations at a high nitrogen content decreases significantly. Therefore, the structure formed during cooling contains a large amount of residual austenite (30 ... 50 $\%$ with rapid cooling in water and up to $70 \ldots 90 \%$ with cooling in the air).

In the structure of the nitrocarburized layer in the martensite-austenite zone, there are numerous dispersed particles, which are individual carbonitride inclusions.

The specific structure of diffusion layers of nitrocarburized steel $09 \mathrm{Cr} 15 \mathrm{Ni} 8 \mathrm{Al}$ for the manufacture of valve plates should also predetermine the specific fatigue properties of these plates.

\section{The effect of nitrocarburizing on the fa- tigue properties of valve plates of steel 09Cr15Ni8Al}

To determine the effect of nitrocarburizing on the fatigue limit of valve steels, two batches of 5 samples each, obtained from 09Cr15Ni8Al steel strips, were investigated. They were subjected to nitrocarburizing in the nitrogen-carbon paste in different modes (1 sample per mode). Nitrocarburized samples were tested for fatigue strength. The test results are presented in Table 3.

The dependences of the endurance limit of 09Cr15Ni8Al steel on the nitrocarburizing modes, obtained in the study of a wide range of temperatures and duration of nitrocarburizing, are shown in Figure 5.

Tab. 3 Dependence of fatigue strength on nitrocarburizing modes

\begin{tabular}{|c|c|c|c|}
\hline \multicolumn{2}{|c|}{ Nitrocarburizing mode } & \multicolumn{2}{c|}{ Steel 09Cr15Ni8Al } \\
\hline Temperature, ${ }^{\circ} \mathrm{C}$ & Duration, hour & Diffusion layer depth, $\mathrm{mm}$ & Fatigue limit $\sigma^{-1}, \mathrm{MPa}$ \\
\hline \multicolumn{2}{|c|}{ Without processing } & - & 698 \\
\hline 550 & 1 & 0.014 & 897 \\
\hline 550 & 3 & 0.022 & 869 \\
\hline 600 & 1 & 0.027 & 771 \\
\hline 600 & 3 & 0.043 & 468 \\
\hline 650 & 1 & 0.042 & 364 \\
\hline
\end{tabular}


An increase in the duration of nitrocarburizing leads to a decrease in the fatigue limit and is due to the coagulation of the precipitated phase, a decrease in the density of dislocations, and, possibly, a partial transition of martensite to austenite. As a result, the degree of blocking of dislocations and resistance to the process of plastic deformation decreases, especially for steel after nitrocarburizing at a temperature of $550{ }^{\circ} \mathrm{C}$.

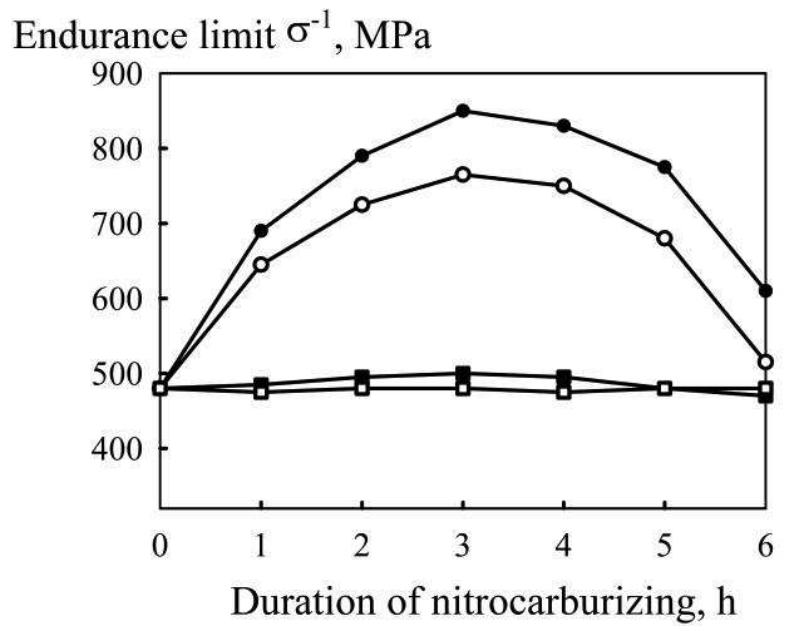

Fig. 5 Dependences of the endurance limit of nitrocarburized steel $09 \mathrm{Cr} 15 \mathrm{Ni8} \mathrm{Al}$ on the duration of nitrocarburizing at different temperatures: $\bullet-550^{\circ} \mathrm{C} ; \circ-600^{\circ} \mathrm{C} ;-650^{\circ} \mathrm{C}, \square$ - without hardening treatment

For example, if we compare the results of studying steel after cold plastic deformation (CPD) and CPD + aging at $470{ }^{\circ} \mathrm{C}$, then fracture occurs after $7 \times 10^{5} \mathrm{cy}-$ cles at $700 \mathrm{MPa}$ [31], and after thermochemical treatment at $550{ }^{\circ} \mathrm{C}$, destruction occurs after $1.5 \times 10^{6} \mathrm{cy}-$ cles. That is, the durability of the material under equal loading conditions is twice as high. This indicates that material with such a state is less sensitive to overload due to the increased ability of the material to relax peak stresses. The results of the analysis of changes in the internal friction of this steel from the heat treatment temperature show that at $550{ }^{\circ} \mathrm{C}$ its damping capacity increases sharply.

The results of all the tests carried out and the temperature dependence of the relative elongation $(\delta$ at $150{ }^{\circ} \mathrm{C}$ ) with a change in the heat treatment temperatures allow us to make a conclusion about the advisability of using nitrocarburizing steel $09 \mathrm{Cr} 15 \mathrm{Ni} 8 \mathrm{Al}$ in the temperature range $550-650{ }^{\circ} \mathrm{C}$. This operation makes it possible to increase the plasticity of the material under operating conditions of the elastic elements of compressor machines without reducing its fatigue properties.

\section{Discussion of results}

Nitrocarburizing of $09 \mathrm{Cr} 15 \mathrm{Ni} 8 \mathrm{Al}$ steel at temperatures of 550 and $600{ }^{\circ} \mathrm{C}$ increases the fatigue limit against the initial value by 1.4-1.8 times. While nitrocarburizing at a higher temperature leads to an unacceptable decrease in the fatigue limit of this steel (below the initial value).

Tab. 4 Modes for carrying out nitrocarburizing of steel plates

\begin{tabular}{|c|c|c|c|}
\hline \multicolumn{2}{|c|}{ Nitrocarburizing mode } & \multicolumn{2}{c|}{ Steel 09Cr15Ni8Al } \\
\hline Temperature, ${ }^{\circ} \mathrm{C}$ & Time, hour & Diffusion layer depth, mm & $\begin{array}{c}\text { Fatigue limit } \sigma^{-1}, \\
\mathrm{MPa}\end{array}$ \\
\hline \multicolumn{2}{|c|}{ Without processing } & - & 498 \\
\hline 550 & 1 & 0.014 & 697 \\
\hline 550 & 3 & 0.022 & 877 \\
\hline 600 & 1 & 0.027 & 869 \\
\hline
\end{tabular}

Table 4 shows the modes for carrying out nitrocarburizing of steel plates and the results of the tests performed.

The optimal modes for carrying out nitrocarburizing of plates made of steel $09 \mathrm{Cr} 15 \mathrm{Ni} 8 \mathrm{Al}$ steel were determined: temperature $600^{\circ} \mathrm{C}$, duration 3 hours. It was concluded that a thin layer of such a coating can release active elements at relatively low heating. This leads to the fact that the reactions of the formation of active nitrogen and carbon atoms proceed in the immediate vicinity of the saturable surface. The latter greatly facilitates their adsorption and diffusion into the depth of the product, increasing the saturation rate. The temperature intensively increases the total depth of the nitrocarburized layer on alloy steel 09Cr15Ni8Al (Fig. 6).
Total depth of the diffusion layer, $\mathrm{mm}$

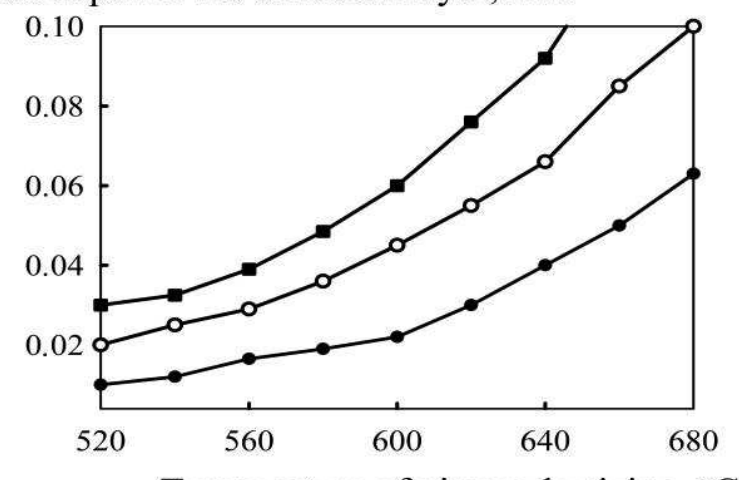

Temperature of nitrocarburizing, ${ }^{\circ} \mathrm{C}$

Fig. 6 Dependence of the depth of the diffusion layer on steel 09Cr15Ni8 Al on the temperature of nitrocarburizing at the different duration of the process: $\bullet-1$ hour; $\bigcirc-3$ hours; -5 hours 
It can be concluded that the depth of the carbonitride zone of alloy steel $09 \mathrm{Cr} 15 \mathrm{Ni} 8 \mathrm{Al}$ is significantly influenced by both nitrocarburizing factors, that is, the temperature and duration of the process. An increase in temperature leads to an almost directly proportional increase in the thickness of the carbon-nitride zone.

The total depth of the nitrocarburized layer, as well as the thickness of the carbonitride crust on the steel surface at the beginning of the saturation process, grows very intensively. However, as the saturation time increases, the growth rate of diffusion layers noticeably decreases.

The main feature of the structure of diffusion layers after nitrocarburizing in the paste is the presence of several distinct zones (the layer is heterogeneous). The number and type of these zones are determined by the temperature of nitrocarburizing.

\section{Conclusion}

So, nitrocarburizing affects the fatigue limit of valve steels ambiguously:

1.Nitrocarburizing of $09 \mathrm{Cr} 15 \mathrm{Ni} 8 \mathrm{Al}$ steel at temperatures of 550 and $600{ }^{\circ} \mathrm{C}$ increases the fatigue limit against the initial value by 1.4-1.8 times, while nitrocarburizing at a higher temperature leads to an decrease in the fatigue limit of this steel.

2.A thin layer of nitrocarburized coating is capable of releasing active elements at relatively low heating, which leads to the fact that the reactions of the formation of active nitrogen and carbon atoms proceed in the immediate vicinity of the saturable surface. And this greatly facilitates their adsorption and diffusion into the depth of the product, increasing the saturation rate.

3. To the depth of the carbonitride zone of alloyed steel $09 \mathrm{Cr} 15 \mathrm{Ni} 8 \mathrm{Al}$, the influence of both nitrocarburizing factors, that is, the temperature and duration of the process are significant.

4.The total depth of the nitrocarburized layer and the thickness of the carbonitride zone on the surface of $09 \mathrm{Cr} 15 \mathrm{Ni} 8 \mathrm{Al}$ steel at the beginning of the saturation process grow very rapidly, but as the saturation time increases, the growth rate of diffusion layers noticeably decreases.

5.The main feature of the structure of the diffusion layers of valve steels, obtained by nitrocarburizing in the nitrogen-carbon paste, is the presence of an inhomogeneous layer with clearly distinguished zones.

\section{Acknowledgments}

This research work had been supported by the Cultural and Educational Grant Agency of the Slovak Republic (KEGA), project No. KEGA 002TnUAD-4/2019 and by the Ministry of Science and Education of Ukraine under the projects „Small-scale energy-saving modules with the use of multifunctional devices with intensive hydrodynamics for the production, modification and encapsulation of granules", project No. $0119 U 100834$ and "Development of a vortex granulator for obtaining granules of porous ammonium nitrate", project No. 0121 U109465.

\section{References}

[1] ZOU, J., HAN, N., YAN, J. et al. (2020). Electrochemical Compression Technologies for High-Pressure Hydrogen: Current Status, Challenges and Perspective. In: Electrochem. Energ. Rev. Vol. 3, pp. 690 - 729. DOI: 10.1007/s41918-020-00077-0

[2] GOVORUN, T. P., LYUBICH, A. I. (2016). Surfacing Layer Development for Cast Iron Object Repair. In: Chemical and Petroleum Engineering. Vol. 52, No. 7 - 8, pp. 502 - 505. DOI: 10.1007/s10556-016-0222-5

[3] GOVORUN, T. P., LYUBICH, A. I. (2017). Theoretical description of the formation of nodular graphite deposited metal for compressor components. In: Welding international. Vol. 31, No. 5, pp. 374 - 379. DOI: $10.1080 / 09507116.2016 .1263460$

[4] SDANGHI, G., MARANZANA, G., CELZARD, A., FIERRO, V. (2019). Review of the current technologies and performances of hydrogen compression for stationary and automotive applications. In: Renewable and Sustainable Energy Reviews. Vol. 102, pp. 150 - 170. ISSN 1364-0321. DOI: 10.1016/j.rser.2018.11.028

[5] ARTYUKHOVA, N. A., ARTYUKHOV, A. E. (2018). Utilization of dust and ammonia from exhaust gases: new solutions for dryers with different types of fluidized bed. In: Journal of Environmental Health Science and Engineering. Vol. 16, No. 2, pp. 1 - 12.

[6] ARTYUKHOV, A., ARTYUKHOVA, N., IVANIIA, A., GALENIN, R. (2017). Progressive equipment for generation of the porous ammonium nitrate with 3D nanostructure. In: Proceedings of the 2017 IEEE 7th International Conference on Nanomaterials: Applications and Properties (NAP 2017), pp. 03NE06-1 - 03NE06-4.

[7] ARTYUKHOV, A. E., ARTYUKHOVA, N. O. (2019). Technology and the main technological equipment of the process to obtain $\mathrm{N}_{4} \mathrm{HNO}_{3}$ with Nanoporous Structure. In: Springer Proceedings in Physics. Vol. 221, pp. 585 594.

[8] ARTYUKHOVA, N. O., KRMELA, J. (2019). Nanoporous structure of the ammonium nitrate granules at the final drying: The effect of 
the dryer operation mode. In: Journal of Nanoand Electronic Physics. Vol 11, No 4, pp. 04006.

[9] ARTYUKHOVA, N. O. (2020). Morphological features of the nanoporous structure in the ammonium nitrate granules at the final drying stage in multistage devices. In: Journal of Nanoand Electronic Physics. Vol. 12, No 4, pp. 04036.

[10] ARTYUKHOV, A., ARTYUKHOVA, N., IVANIIA, A. (2018). Creation of software for constructive calculation of devices with active hydrodynamics. In: 14th International Conference on Advanced Trends in Radioelectronics, Telecommunications and Computer Engineering, TCSET 2018 - Proceedings, 2018-April, pp. 139 - 142.

[11] ARTYUKHOV, A., OBODIAK, V., BOIKO, P., ROSSI, P. (2017). Computer modeling of hydrodynamic and heat-mass transfer processes in the vortex type granulation devices. In: CEUR Workshop Proceedings, Vol. 1844, pp. $33-47$.

[12] OBODIAK, V., ARTYUKHOVA, N., ARTYUKHOV, A. (2020). Calculation of the residence time of dispersed phase in sectioned devices: Theoretical basics and software implementation. In: Lecture Notes in Mechanical Engineering, pp. 813 - 820.

[13] ARTYUKHOV, A., ARTYUKHOVA, N., KRMELA, J., KRMELOVÁ, V. (2020). Granulation machines with highly turbulized flows: Creation of software complex for technological design. In: IOP Conference Series: Materials Science and Engineering, Vol. 776, No 1, 012018.

[14] ARTYUKHOV, A., ARTYUKHOVA, N., KRMELA, J., KRMELOVÁ, V. (2020). Complex designing of granulation units with application of computer and software modeling: Case "Vortex granulator". In: IOP Conference Series: Materials Science and Engineering, Vol. 776, No 1, 012016.

[15] BUDNIK, O.A., SVIDERSKII, V.A., BUDNIK, A.F. et al. (2016). Composite Material for Chemical and Petrochemical Equipment Friction Assemblies. In: Chem Petrol Eng. Vol. 52, pp. 63 - 68 (2016). DOI: 10.1007/s10556-016-0149-x

[16] ALI, S.M., HUI, K.H., HEE, L.M., LEONG, M.S., ABDELRHMAN, A.M., AL-OBAIDI, M.A. (2019). Observations of changes in acoustic emission parameters for varying corrosion defect in reciprocating compressor valves. In: Ain Shams Engineering Journal. Vol. 10, No. 2, pp.
253 - 265. ISSN 2090-4479. DOI: 10.1016/j.asej.2019.01.003

[17] KUSMIČ, D, FALTEJSEK, P. (2019). Corrosion Resistance of Low Temperature Plasma Nitrided X12CrMoWVNbN10-1-1 Martensitic Stainless Steel. In: Manufacturing Technology. Vol. 19, No. 4, pp. 619 - 623. DOI: $10.21062 /$ ujep/344.2019/a/12132489/MT/19/4/619.

[18] SCHNEIDER, R.S.E. (2015). 9 - Austenitic nitriding and nitrocarburizing of steels, Editor(s): Eric J. Mittemeijer, Marcel A.J. Somers, Thermochemical Surface Engineering of Steels, pp. 373 - 400e. Woodhead Publishing. ISBN 9780857095923.

DOI: 10.1533/9780857096524.3.373.

[19] DOSSETT, J., L. TOTTEN, G. E. (2013). Nitriding and Nitrocarburizing of Steels, Steel Heat Treating Fundamentals and Processes. Vol 4A. ASM Handbook. ASM International. ISBN electronic: 978-1-62708-165-8.

[20] LEE, I. (2019). Combination of plasma nitriding and nitrocarburizing treatments of AISI 630 martensitic precipitation hardening stainless steel. In: Surface and Coatings Technology. Vol. 376, pp. 8 - 14. ISSN 0257-8972. DOI: 10.1016/j.surfcoat.2018.12.078.

[21] ANJOS, A.D., SCHEUER, C.J., BRUNATTO, S.F., CARDOSO, R.P. (2015). Low-temperature plasma nitrocarburizing of the AISI 420 martensitic stainless steel: Microstructure and process kinetics. In: Surface and Coatings Technology. Vol. 275, pp. 51 - 57. ISSN 0257-8972. DOI: 10.1016/j.surfcoat.2015.03.039.

[22] YEH, S., CHIU, L., CHANG, H. (2011). Effects of Gas Nitriding on the Mechanical and Corrosion Properties of SACM 645 Steel. In: Engineering. Vol. 3, No. 9, pp. 942 - 948. DOI: 10.4236/eng.2011.39116.

[23] FOERSTER, C.E., ASSMANN, A., DA SILVA, S.L.R., NASCIMENTO, F.C., LEPIENSKI, C.M., GUIMARÃES, J.L., CHINELATTO, A.L. (2010). AISI 304 nitrocarburized at low temperature: Mechanical and tribological properties. In: Surface and Coatings Technology. Vol. 204, No. 18-19, pp. $3004-3008$. ISSN 0257-8972. DOI: 10.1016/j.surfcoat.2009.12.030.

[24] GARCÍA-MENDOZA, A.P., VARGASGUTIÉRREZ, G., LÓPEZ-CUEVAS, J. (2018). Surface microstructural evolution of AISI $304 \mathrm{~L}$ stainless steel oxy-nitrocarburized 
in a cyanide-free salt bath and its potential application in solar collectors. In: Surface and Coatings Technology. Vol. 353, pp. 190 - 198. ISSN 0257-8972. DOI: $10.1016 /$ j.surfcoat.2018.08.078.

[25] SLIMA, S. (2012). Ion and Gas Nitriding Applied to Steel Tool for Hot Work X38CrMoV5 Nitriding Type: Impact on the Wear Resistance. In: Materials Sciences and Applications. Vol. 3, No. 9, pp. 640 - 644. DOI: 10.4236/msa.2012.39093.

[26] JASIŃSKI, J. J., FRĄCZEK, T., KURPASKA, L., LUBAS, M., SITARZ, M. (2018). Effects of Different Nitriding Methods on Nitrided Layer Structure and Morphology. In: Archives of Metallurgy and Materials. Vol. 63, No. 1, pp. 337 - 345. DOI: $10.24425 / 118946$.

[27] FOSSATI, A., BORGIOLI, F., GALVANETTO, E., BACCI, T. (2006). Glow-discharge nitriding of AISI 316L austenitic stainless steel: influence of treatment time. In: Surface and Coatings Technology. Vol. 200, No. 11, pp. 3511 - 3517. ISSN 0257-8972. DOI: 10.1016/j.surfcoat.2004.10.122.

[28] FERNANDES, F.A.P., HECK, S.C., PEREIRA, R.G., LOMBARDI-NETO, A.,
TOTTEN, G.E., CASTELETTI, L.C. (2010). Wear of plasma nitrided and nitrocarburized AISI 316L austenitic stainless steel. In: Journal of Achievements in Materials and Manufacturing Engineering. Vol. 40, No. 2, pp. 175 - 179.

[29] IVANOV, I. V., MOHYLENETS, M. V., DUMENKO, K. A., KRYVCHYK, L., KHOKHLOVA, T. S., PINCHUK, V. L. (2020). Carbonitration of a tool for pressing stainless steel pipes. In: Journal of Engineering Sciences. Vol. 7, No. 2, pp. C17 - C21. DOI: 10.21272/jes.2020.7(2).c3.

[30] JACQUET, P., COUDERT, J.B., LOURDIN, P. (2011). How different steel grades react to a salt bath nitrocarburizing and post-oxidation process: Influence of alloying elements. In: Surface and Coatings Technology. Vol. 205, No. 16, pp. 4064 - 4067. ISSN 0257-8972. DOI: 10.1016/j.surfcoat.2011.02.049.

[31] KRMELA, J, HOVORUN, T., BERLADIR, K., ARTYUKHOV, A. (2021). Increasing the Structural Strength of Corrosion-resistant Steel for Elastic Components of Diaphragm Compressor. In: Manufacturing Technology. Vol. 21, No. 2, pp. 207 - 213. DOI: 10.21062/mft.2021.034. 